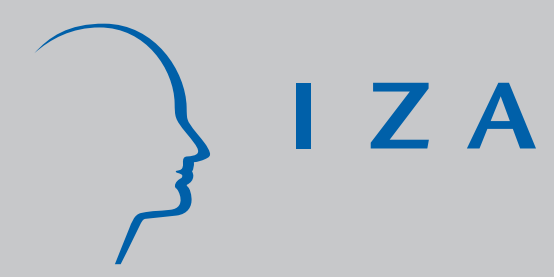

IZA DP No. 1319

Mass Migration to Israel and Natives'

Transitions from Employment

Sarit Cohen-Goldner

M. Daniele Paserman

September 2004 


\title{
Mass Migration to Israel and Natives' Transitions from Employment
}

\author{
Sarit Cohen-Goldner \\ Bar-Ilan University \\ M. Daniele Paserman \\ Hebrew University and IZA Bonn
Discussion Paper No. 1319
September 2004

\author{
IZA \\ P.O. Box 7240 \\ 53072 Bonn \\ Germany \\ Phone: +49-228-3894-0 \\ Fax: +49-228-3894-180 \\ Email: iza@iza.org
}

Any opinions expressed here are those of the author(s) and not those of the institute. Research disseminated by IZA may include views on policy, but the institute itself takes no institutional policy positions.

The Institute for the Study of Labor (IZA) in Bonn is a local and virtual international research center and a place of communication between science, politics and business. IZA is an independent nonprofit company supported by Deutsche Post World Net. The center is associated with the University of Bonn and offers a stimulating research environment through its research networks, research support, and visitors and doctoral programs. IZA engages in (i) original and internationally competitive research in all fields of labor economics, (ii) development of policy concepts, and (iii) dissemination of research results and concepts to the interested public.

IZA Discussion Papers often represent preliminary work and are circulated to encourage discussion. Citation of such a paper should account for its provisional character. A revised version may be available directly from the author. 


\section{ABSTRACT \\ Mass Migration to Israel and Natives' Transitions from Employment}

This paper studies the impact of mass migration from the Former Soviet Union to Israel on natives' probability of moving from employment to non-employment in a segmented labor market that is defined by various combinations of schooling, occupation, industry, district of residence and experience. We find that the share of immigrants in a given labor market segment is generally positively associated with the probability of natives to move from employment in that segment to non-employment, both for males and females. However, when segment fixed-effects are added, this effect is substantially reduced for males, and disappears or is even reversed for females. We conclude that immigrants are negatively selected into occupations with high turnover and that natives were not facing higher probability to exit employment due to immigrants' presence in a certain occupation. Allowing the effect to vary across natives with different levels of education and experience reveals that young men, educated men and workers in the private sector are adversely affected by the presence of immigrants.

JEL Classification: J00, J30, J61, J21, F22

Keywords: immigration, labor demand, labor supply, segmented labor markets, employment transitions

Corresponding author:

M. Daniele Paserman

Department of Economics

Hebrew University

Jerusalem, 91905

Israel

Email:dpaserma@shum.huji.ac.il

\footnotetext{
* We wish to thank seminar participants at the 2002 SOLE meetings in Baltimore, at Tel Aviv University and at Hebrew University for helpful comments. We acknowledge generous financial support from the Maurice Falk Institute for Economic Research in Israel. Stas Krasinski and Royi BenIvry provided excellent research assistance. All errors are our own.
} 


\section{Introduction}

From 1989 to 2000 more than 1 million Jews migrated from the former SovietUnion (FSU) to Israel, increasing its population and labor force by extraordinary magnitude. Not only was the size of this migration wave unique, but also its character: contrary to immigrants in other Western countries, FSU immigrants had on average more years of schooling than natives and most of them worked in white-collar occupations in the FSU. In this paper we analyze the impact of the FSU immigrants on the employment outcomes of Israeli natives.

While previous studies have primarily focused on the effect of migration on the levels of natives' wages and employment, we prefer to concentrate our attention in particular on the transition probabilities of natives between employment and nonemployment. There are several reasons for this shift in focus. First, employment outcomes of natives are usually at the center of the public discourse in immigrant receiving countries, possibly because the short-term pains of unemployment and job loss are felt more acutely and have a larger echo in the media, creating negative attitudes towards immigrants among natives and policymakers. Second, much of the existing literature has found little or no effects of immigration on natives' outcomes, suggesting that increases in labor supply due to immigration may be counterbalanced by offsetting flows of native capital and labor. Hence, we can shed some light on the importance of offsetting native flows by focusing on transitions between different labor market states, on the reasons for these transitions, and on whether different personal characteristics may affect transition probabilities differently. Finally, focusing on transition probabilities allows us to discriminate between adverse employment effects due to job loss and those due to difficulties in finding employment among the already unemployed. This distinction is important to fully 
understand the dynamic impact of migration on natives' labor market outcomes, yet it has received little attention in the literature on migration, both in Israel and abroad. We should stress that this analysis is feasible in our setting because of the sheer magnitude of the mass migration wave and because of the rotating panel nature of our data.

An additional novel feature of our work is that we take a longer run perspective on immigration. We analyze whether different waves of immigration, characterized by different levels of human capital and of information about the Israeli labor market, affected the labor market differently. Since the transition of immigrants into a new labor market is a gradual process, and the main dynamics of this process come from immigrants' occupational mobility, we believe that natives may face changing labor market conditions, even years after the arrival of the immigrants.

It is natural to expect that a large migration wave would have an adverse effect on employment rates and wages of native workers. However, various studies on the impact of the FSU immigrant wave on labor market outcomes of Israeli natives suggest that there is no conclusive evidence for such an effect. Friedberg (2001) studied the impact of immigrants on wages of natives. Taking an instrumental variable approach to control for the occupational selectivity of the immigrants, she shows that the mass migration had no effect on wages of natives. Cohen and Tai-Hsieh (2001) studied the effect of this migration wave on macroeconomic variables such as average wage, the current account deficit, investment and others. They find that during the peak of the wave (1990-1991), immigration did suppress average real wages of natives, but by 1997, the wage loss had been completely recovered. Eckstein and Weiss (forthcoming) have analyzed the wage convergence properties of FSU immigrants to those of native Israeli workers by using a cross sectional data from 
1990 to 2000 that included a large sample of immigrants. The main finding is that while the occupational distribution of immigrants converges to that of natives, there is no convergence in wages.

Altogether the results in the aforementioned studies are consistent with much of the international evidence accumulated on the impact of immigration on host country wages and employment. A number of studies exploit variation in immigrant rates across United States cities and over time to measure the impact of immigration on local labor market outcomes (Altonji and Card (1991); LaLonde and Topel (1991) and Goldin (1994)). These studies typically conclude that immigration had little or no adverse impact on natives' wages and employment. Pischke and Velling (1997) obtain similar results when looking at variation in immigrant rates across German counties. Other studies, which focused on natural experiments generated by political factors in the sending country (Card (1990); Hunt (1992) and Carrington and de Lima (1996)), also found surprisingly little effects of migration.

One of the conceptual problems of the cross-market approach, raised by Borjas, Freeman and Katz (1996), is that an increase in the labor supply in a certain city (due to immigration) can be diffused across the economy by intercity trade, movements of capital or by outflows of natives. Acknowledging this problem, a recent paper by Card (2001) assumes that immigrants and natives are perfect substitutes within occupations and cities. Under this assumption, he does find that occupation-specific wages and employment rates are systematically lower in cities with higher relative supplies of workers in a given occupation. Similarly, Borjas (2003) claims that any approach that attempts to exploit geographic variation in immigrant rates is troublesome because of the strong currents that tend to equalize economic conditions across cities and regions. He therefore uses only variation in the human capital mix of immigrants, (i.e., the 
combination of schooling and experience) to study the effect of immigration on different groups of natives. He finds that, within groups, immigrants did have an adverse effect on wages and employment opportunities of natives.

In this paper we study the effect of immigrants on the probability of natives to enter or exit employment in a well-defined labor market segment. Following the recent criticisms of the local labor market approach, we take particular care to define the segments in such a way that they can be viewed as isolated markets with limited possibilities for workers to move between them. We consider five definitions of labor market segments in which immigrants and natives compete: (a) 2-digit occupation cells, (b) residential district interacted with 1-digit occupation, (c) schooling interacted with 1-digit occupation, (d) 1-digit industry interacted with 1-digit occupation and (e) schooling interacted with experience.

The empirical analysis is based on micro data from the Israeli Labor Force Survey (LFS) from 1989 to 1999. The special structure of the LFS allows us to follow natives and immigrants over a period of eighteen months: each household is interviewed for two consecutive quarters, followed by a break for two quarters, and is interviewed again for two consecutive quarters. Our identification strategy exploits variation in the distribution of immigrants across occupations, industries, geographic districts and skill levels, and over time.

Our results indicate that, for both men and women, regardless of the definition of the labor market segments, a higher share of immigrants in the segment is associated with a higher probability of natives to move from employment in the segment to unemployment, especially if the segmentation of the labor market is based on occupational categories. However, once we control for segment fixed effects, the effect of immigrants' share is substantially reduced and becomes mostly insignificant 
for men, and at times even negative for women. This finding suggests that immigrants selectively end up working in jobs with high turnover.

We also find some evidence that migration affected different categories of workers differently, where young men, educated men, and workers in the private sector are most likely to move to non-employment as a result of immigration. We try to examine whether the near absence of any causal adverse impact in the basic model is attributable to natives' flows out of segments with high immigrant shares. We find no evidence that a high share of immigrants in their labor market segment leads natives to quit voluntarily, nor do we find that the immigrant wave affected young natives' career choices.

The rest of the paper is organized as follows: the next section presents a brief background of the absorption of FSU immigrants in the Israeli labor market. In Section 3 we describe more in detail the data and samples used in the analysis. In Section 4 we present the results on the effect of immigration on the transitions from employment to non-employment. In Section 5 we investigate whether the effect of immigration was homogeneous: we look at whether immigrants with different amounts of tenure in Israel affected natives differentially, and whether the effect of immigration was the same for all natives. In Section 6 we examine whether natives voluntarily flowed out of labor market segments with high immigrants shares, and whether young people's career choices were affected by immigration. Section 7 concludes.

\section{Background}

In this section we give a brief background of the mass migration wave from the Former Soviet Union (FSU) to Israel in the past decade, and describe the evolution of the occupational and residential distribution of natives throughout this period. This 
will give us some preliminary understanding about whether the mass migration wave affected native choices.

From late 1989 until 2001, over a million of immigrants from the FSU arrived in Israel, increasing its population and labor force by extraordinary rates. At the peak of this wave during 1990 and 1991, over 330 thousand FSU Jews immigrated to Israel, increasing Israel's potential labor force by 8 percent and its population by 15 percent (see Figures $1 \mathrm{a}, 1 \mathrm{~b}^{1}$ ). The most notable characteristic of these immigrants is their high level of education. Table 1 presents the educational distribution of male and female natives and immigrants by year of arrival. Over 69 percent of all FSU male and female immigrants had at least some college education and over 40 percent were college graduates. The share of college-educated natives, on the other hand, is only about 35 percent, and only 22 percent of natives are college graduates. Table 1 also reveals that immigrants who arrived in the early wave (1989-1993) were, on the average, more educated than those who arrived in the later wave.

It is useful to distinguish between the stock of all post-1989 immigrants who are present in a segment and the stock of only recent immigrants: in any given year $t$, this is the number of immigrants who arrived in Israel during the three-year window prior to year $t$. In Table 2 we present the one-digit occupational distribution of natives and immigrants, both recent and overall. Independently of the definition of immigrants, Table 2 shows that immigrants are more concentrated than natives in skilled industrial occupations and in unskilled occupations in both sub-periods and that the distribution of natives is almost unchanged between the two periods. At first glance, there is no evidence that immigrants adversely affected the occupational distribution of natives.

\footnotetext{
${ }^{1}$ The figures present the flow (1a) and the stock (1b) of immigrants at the ages of 25-64 as a percentage of the total population in this age group (Jews and non-Jews).
} 
As for the distribution of immigrants, it is worthwhile to note that early immigrants (1989-1993) were more likely than later immigrants to be absorbed in academic and professional occupations (probably reflecting their higher measured human capital), but were also more likely to be absorbed in unskilled occupations (probably reflecting the fact that the size of the initial wave was so large that for many immigrants it was difficult to find a job suitable to their skills).

In addition, we see that in the latter period the occupational distributions of recent and all immigrants differ substantially. In particular, recent immigrants are more concentrated at the low end of the occupational spectrum. This finding is quite intuitive, for two reasons: first, later immigrants tended to be less educated than early immigrants; second, the absorption of immigrants in the labor market is a gradual process that involves occupational upgrading as the immigrant studies the new language and the conditions and technology of the new labor market.

In contrast to earlier waves of immigrants to Israel during the $50 \mathrm{~s}$ and the $60 \mathrm{~s}$, FSU immigrants who arrived in the 90's could choose where to live right after arrival. Table 3 presents the residential distribution of immigrants and natives. The absolute majority of natives live in cities and metropolitan areas. The residential distribution of immigrants is quite similar to that of natives except that they seem to be more likely to be located in the South than in the North. Moreover, recent immigrants in the second sub-period (1994-1999) are substantially more concentrated in the South than immigrants who arrived at the beginning of the 1990s. ${ }^{2}$

Overall, the data suggests that the occupational and residential distribution of natives remained relatively stable throughout the 1990s. This can be interpreted as

\footnotetext{
${ }^{2}$ This is likely to be related to the affordability of housing as a result of sizeable government-initiated construction in the South.
} 
evidence that the mass migration wave had little effect on natives' choices. However, the finding that the stock of natives in a particular occupation or residential area was unaffected by the migration wave does not necessarily imply that the flows (between employment and non-employment, between occupations or between localities) did not change as well. In the following sections we examine whether natives' employment transitions in a given labor market segment depend on immigrants' share in the segment.

\section{Data and Preliminary Results}

We use micro data from the annual Israeli Labor Force Survey (LFS) of 19891999. Each household in the LFS is interviewed for two consecutive quarters, followed by a break for two quarters, and is interviewed again for two consecutive quarters. Hence, the LFS allows us to follow natives and immigrants over a period of up to eighteen months. To study the impact of immigration on natives' transitions between employment and non-employment, we focus on natives and pre-1989 immigrants who appeared in the first two LFS interviews between 1989 and $1999 .^{3}$ The male sample includes men between 25 and 65 , the female sample includes women between 25 and 60 . We do include non-Jews in our sample, but we exclude ultra-orthodox Jews, immigrants whose age at arrival was smaller than 25 , and people who reported more than 30 years of schooling.

In our analysis we use two definitions for immigrants: (1) those who arrived in Israel during the three years prior to the interview (referred as recent immigrants) and

\footnotetext{
${ }^{3}$ The attrition rate of households between the first and second interview of the LFS is about $20 \%$. The attrition rate of households between the $2^{\text {nd }}$ and the $3^{\text {rd }}$ interview is much higher. At this stage, we do not perform any corrections for non-random attrition.
} 
(2) all immigrants who arrived after 1989 (referred as total immigrants). Overall we have 104,558 observations.

Table 4 presents summary statistics of our data by gender. As can be seen, the average of recent immigrants, across all years, is about 5 percent, while the average total stock of immigrants is 9 percent for males, and 10 percent for females. The average quarterly rate of transition from employment to non-employment during 1989-1999 is 4.52 percent for native males, and 7.27 for native females. The average quarterly rate of transition from non-employment to employment is 17.54 percent for males, and 9.06 for females.

\section{Transitions From Employment to Non-Employment}

One of the main objectives of this paper is to study the dynamic implications of the immigration wave on natives' outcomes. This task is feasible in our particular setting, given the large size of the FSU immigration wave, and the structure of our data, where we can observe workers' employment status at three-month intervals. This time interval is long enough to allow both non-negligible changes in the percentage of immigrants in a cell and adjustments by employers to the size of their workforce. At the same time, the interval is probably not sufficiently long to allow longer-term adjustments in the behavior of workers and firms (such as investments in physical and human capital).

We first analyze the effect of the immigrant flow (i.e., recent immigrants) on the transition probability from employment to non-employment. The model is a probit model of the form:

$$
\begin{aligned}
& P\left(\text { NotEmployed }_{i j t}=1 \mid \text { Employed }_{i j t-1}=1 \text { immshare }_{j t}, X_{i j t}\right)= \\
& \Phi\left(\beta_{\text {immshare }_{j t}}+\gamma^{\prime} X_{i j t}+\delta_{t}+\eta_{j}\right) \text {. }
\end{aligned}
$$


where NotEmployed $_{i j t}\left(\right.$ Employed $\left._{i j t-1}\right)$ is a dummy variable equal to 1 if worker $i$ in labor market segment $j$ at time $t(t-1)$ is non-employed (employed), ${ }^{4}$ and zero otherwise, immshare $_{j t}$ is the share of recent immigrants in segment $j$ at time $t, X_{i j t}$ is a vector of individual characteristics, ${ }^{5}$ and $\delta_{t}$ and $\eta_{j}$ are time fixed effects and segment fixed effects, respectively. We use five different definitions of labor market segments: two digit occupation cells, cells defined by one-digit occupation interacted in turn with district of residence, schooling, and one-digit industry and cells defined by schooling interacted with potential experience (where potential experience is defined as age - years of schooling -6). ${ }^{6}$ The model is estimated both with and without labor market segment fixed effects. The former should be viewed primarily as a descriptive exercise, while in the latter the parameter $\beta$ can be interpreted as a causal effect under the assumption that there are no time-varying unobservables that are correlated with the immigrant share.

Note that our sample is restricted to those who were employed at the time of the first LFS interview, and the dependent variable is a dummy for non-employment at the time of the second LFS interview. The results of this estimation are presented in Table 5. When we exploit both time series and cross-sectional variation in immigration rates (the no-fixed effects model), we find that there was a displacement effect, and that this effect was larger for females than for males. According to the first

\footnotetext{
${ }^{4}$ At this stage, we choose not to make a distinction between unemployment and out of the labor force states. This is motivated in part by the fact that there is a considerable number of direct transitions, in both directions, between employment and out of the labor force. See also Beenstock and Klinov (1996). ${ }^{5}$ The vector of individual characteristics in this and the following models includes years of schooling, years of potential experience, experience squared, a marital status dummy, dummies for the presence of children aged 0-4, 5-14 and 15-17, 3 ethnic origin dummies (Non-Jews, Asia-Africa, Europe-AmericaOceania, with third generation Israelis the omitted category), a dummy for foreign born status, and years since immigration (which takes on zero for natives). All models include a full set of calendar quarter dummies.

${ }^{6}$ For the moment, we assume that experience acquired abroad is equivalent to experience acquired in Israel.
} 
four definitions of the labor market, a ten percentage point increase in the proportion immigrants in a cell is associated with an increase in the job loss probability by between 0.7 and 1.1 percentage points for men, and between 2.5 and 4.5 percentage points for women. These estimates correspond to an elasticity of job loss probability with respect to the immigration rate of about 0.08 for men, and about 0.16 for women.

However, when we include cell fixed effects, the effect becomes very small for men (although always positive), and null or even negative for women. This evidence suggests that immigrants tend to cluster in labor market sectors with high turnover rates. The fifth definition we use (schooling interacted with experience) yields different results. For men we find a small displacement effect in the specification without fixed effects, and a larger (and significant) effect in the specification with fixed effects. The size of the fixed effects coefficient implies that a 10 percentage point increase in the immigration share raises the probability of job loss by nearly half a percentage point. For women, immigrants' presence in a cell leads to a lower transition rate from employment to non-employment. However, inclusion of cell fixed effects washes away this result completely.

One should keep in mind that the first four definitions of the labor market are based on the occupational choices of immigrants, and may therefore be subject to selfselection (we come back to this point in Section 6). On the other hand, the fifth definition of the labor market is based exclusively on measures of human capital that presumably had been already determined at the time of immigration.

It may be argued that looking at the immediate impact of the flow of immigrants is not the appropriate way to measure the extent of the effect of the migration wave on the local labor market. The immigrant absorption process is a long and gradual one: as immigrants learn new skills, they move up the occupational ladder, so that the inflow 
of immigrants in a given labor market segment in the first few years since immigration does not fully capture the long term effects of immigration. Therefore, we also estimate a model in which we use the stock of all post-1989 immigrants in a labor market cell as our basis to measure of the immigration rate. The results are presented in Table 6.

The pattern here is similar to that of Table 5: for males there appears to be a small but significant displacement effect of immigrants in the cross section, but this is due almost exclusively to the clustering of immigrants in high turnover segments of the labor market, since the effect completely disappears when cell fixed effects are included. For females, however, according to the first four definitions of the labor market, which all depend on occupation, the within-sector analysis suggests that a higher share of immigrants in a sector actually lowers the probability of transition between employment and non-employment. According to the fifth definition (experience interacted with schooling), female natives are not significantly affected by the presence of immigrants in their labor market segment. Altogether, using the immigrant stock as our measure does not fundamentally alter the conclusions for native males, but it shows that the long-term process of immigrants' occupational upgrading significantly affects female natives, but in a direction opposite to that predicted by economic theory.

\section{Is the Effect of Immigrants Homogeneous?}

Immigrants' Tenure in Israel. To further explore how the gradualism of the absorption process affects natives' labor market outcomes, we now study whether immigrants with different amounts of tenure in Israel affect natives differentially. We consider the following econometric specification: let $I M M_{j s t}$ be the number of 
immigrants in cell $j$ at time $t$ with $s$ years of tenure in Israel. A fully flexible specification of the relationship between transition probabilities and immigrants would then be:

$$
\begin{aligned}
& P\left(\text { NotEmployed }_{i j t}=1 \mid \text { Employed }_{i j t-1}=1,\left\{\text { IMMX }_{j s t}\right\}_{s=0}^{10}, X_{i j t}\right)= \\
& =\beta_{0} I M M_{j 0 t}+\beta_{1} I M M_{j 1 t}+\ldots+\beta_{10} I M M_{j, 10, t}+\gamma^{\prime} X_{i j t}+\eta_{j}+\delta_{t} .
\end{aligned}
$$

There might not be enough degrees of freedom to separately estimate precisely each one of the $\beta$ parameters, so we choose a more parsimonious specification:

$$
\beta_{s}=\lambda_{0}+\lambda_{1} s
$$

Assumption (3) states that the effect of immigrants changes linearly with their tenure: in this case, equation (2) reduces to a probit of the transition probability on the cumulative number of immigrants and on the cumulative number of immigrant-years in a cell and can be written as

$$
\begin{gathered}
P\left(\text { NotEmployed }_{i j t}=1 \mid \text { Employed }_{i j t-1}=1,\left\{\text { IMMX }_{j s t}\right\}_{s=0}^{10}, X_{i j t}\right)= \\
=\lambda_{0} \sum_{s} I M_{j s t}+\lambda_{1} \sum_{s} s \times I M M_{j s t}+\gamma^{\prime} X_{i j t}+\eta_{j}+\delta_{t}
\end{gathered}
$$

The signs of $\lambda_{0}$ and $\lambda_{1}$ are a-priori ambiguous: on one hand, if immigrants are poor substitutes for natives when they arrive, but then natives become easily substitutable for immigrants as these acquire local skills, we would expect $\lambda_{0}$ to be approximately zero, and $\lambda_{1}$ to be positive; on the other hand, immigration might have a short-run displacement effect, but as time since immigration increases it is more likely that the local factors of production (native workers and capital) adjust so as to diffuse the effects of immigration: in this case, $\lambda_{0}$ would be positive and $\lambda_{1}$ would be negative. Note that a value of $\lambda_{1}$ equal to zero implies that the effect of immigrants is the same regardless of their amount of tenure in Israel; in this case, equation (2) reduces to a probit of the transition probability on the cumulative number of immigrants in a labor 
market cell. This specification is very similar to the specifications in Table 6, but for the fact that here the right-hand side variable is the number of immigrants in a cell, rather than the immigrant share. Therefore, we will also estimate equation (4) assuming $\lambda_{1}$ equal to zero. We can view this specification as a robustness check for Tables 5 and 6: this allows us to examine whether an increase in the number of immigrants has any effect on transition probabilities, holding constant the size of the native workforce in the sector. By contrast, by looking only at the immigrant share, we may miss the fact that natives move out of labor market segments with a high influx of immigrants, thus leaving total labor supply in that segment unaltered.

The results are presented in Table 7 using two definitions of the labor market segments: two-digit occupation and schooling interacted with experience. In columns (1) and (3) we estimate the model derived assuming that $\lambda_{1}$ is equal to zero: for males, we find a small displacement effect when using two-digit occupation cells, and a larger effect when using schooling-experience cells; for females, we find that immigrants either lower or have no effect on transition probabilities. In columns (2) and (4), we estimate the more flexible model, and we find that $\lambda_{1}$ is negative and marginally significant for males, and essentially zero for females. In other words, native males were adversely affected especially by the presence of new immigrants who had just arrived in the country. Increasing the number of new arrivals by 5,000, leads to an increase of 2.8 percentage points in the probability of native males to move from employment to non-employment. Had these immigrants have been in Israel for 5 years, the effect would have been only 1.1 percentage points. These results indicate that the effect of the entrance of immigrants on natives' transition to nonemployment is stronger than the (counterbalancing) effect of immigrants' occupational upgrading process. 
Differential Effects by Schooling, Experience, and Economic Sector. Up to now our analysis has assumed that the immigrant wave had a uniform effect on the Israeli labor market. However, it is possible that different categories of native workers were affected differentially by the immigration wave. For example, since immigrants are highly educated and have no experience in the Israeli labor market, they may have increased the relative supply of this particular type of workers, hence affecting young and educated natives more than others. It is also possible that natives in the public sector are affected differently by the presence of immigrants than natives in the private sector, if the terms of employment and the degree of competitiveness differ between these sectors. The results of these specifications are presented in Table 8 using two-digit occupations as our labor market segments (the results in the other specifications were analogous). All models include cell fixed effects. For males we find that within occupations, young natives are significantly more affected than older natives. As expected, there is also evidence that educated workers and workers in the private sector are more likely to move to non-employment as a result of the influx of immigrants into their labor market cell. The fact that young natives are more likely to be affected may indicate that the large influx of immigrants caused more mobile workers (including highly educated workers) to seek alternative career paths. As expected, public sector workers are essentially shielded from any negative effects of immigration, whereas the effect for private sector workers are similar in magnitude to those found for the overall population. The estimates for female natives are not always precisely estimated, although the pattern of signs is similar to that found for males. The interesting finding here is that female natives in the public sector are facing significantly lower probabilities to move from employment to non-employment 
due to the presence of immigrants in their occupation, whereas female natives in the private sector are not affected by immigrants in their labor market cell.

\section{Immigrant Inflows and Native Outflows}

We now turn to the question of whether the influx of immigrants led to natives leaving certain sectors. We have already seen that the displacement effect attributable to immigrants is similar in magnitude regardless of whether we do or do not hold constant the number of immigrants in a cell (Tables 6 and 7). At first glance, this finding seems to rule out the possibility that the absence of a large adverse impact of immigration is due to a substantial outflow of natives from sectors with large immigrant influxes.

The question of whether immigrants led natives to leave certain sectors can be addressed by studying whether transitions from non-employment to employment were voluntary or involuntary. This can be done using a multinomial choice model for the three different outcomes: remained employed, was fired, quit voluntarily. However, we face a missing data problem: the reason for which workers are no longer employed is available only for those who are currently unemployed, and is missing for those currently out of the labor force. Rather than throwing away the missing data, we create a special category - moved directly from employment to out of the labor force - and estimate a multinomial logit model. The probability that native worker $i$, employed in cell $j$ at time $t-1$, is in state $k$ at time $t$ is

$$
P\left(Y_{i j t}=k \mid i m m_{j t}, X_{i j t}\right)=\frac{\exp \left(\beta_{k} i m m_{j t}+\gamma^{\prime}{ }_{k} X_{i j t}+\delta_{k t}+\eta_{k j}\right)}{1+\sum_{k=2}^{K} \exp \left(\beta_{k} i m m_{j t}+\gamma^{\prime}{ }_{k} X_{i j t}+\delta_{k t}+\eta_{k j}\right)}
$$

where the possible states are: $(1-$ still employed, 2 - unemployed who was fired, 3 unemployed who quit, 4 - out of the labor force), and the other variables are defined 
as above. In Table 9 we present the $\beta_{k}$ estimates, representing the effect of the immigrant share on the log odds of being in state $k$ rather than being still employed. We use two different segmentations of the labor market: two-digit occupation cells and schooling-experience cells. The model is always estimated with cell fixed effects.

For males, we find some evidence that an increase in the immigrant share raises the probability of being fired, while it essentially has no effect on the probabilities of quitting or moving directly to out of the labor force. The coefficients however are small (the elasticity in the probability of being fired with respect to the immigrant share is between 0.075 and 0.1 ) and generally imprecise, even though the pattern of signs and magnitudes is the same in both specifications. For females, the results are mixed: using the occupational segmentation, we find that the presence of immigrants in a cell led to lower probabilities of being fired, quitting, and moving to out of the labor force - in accordance to the puzzling results of Tables 5 and 6 . On the other hand, using the schooling-experience segmentation, the results are similar in magnitude to those found for males, but less precise. Overall, this table suggests that transitions from employment to unemployment as a result of immigration were mostly involuntary, even though the adverse impact is quite small.

Finally, we return to the question of whether young workers are likely to modify their career decisions in response to the immigrant wave. In particular, we ask whether the occupational choices of young workers (aged 25 to 35) are affected in any way by the occupational distribution of immigrants. Is it possible that a high concentration of immigrants deters young workers from choosing certain occupations? We set up a conditional logit model for occupational choice:

$$
P\left(\text { Occup }_{i t}=k\right)=\frac{\exp \left(\beta_{i m m_{k t}}+\alpha_{k}+\gamma_{k}{ }^{\prime} X_{i t}\right)}{\sum_{k=1}^{K} \exp \left(\beta i m m_{k t}+\alpha_{k}+\gamma_{k}{ }^{\prime} X_{i t}\right)}
$$


The probability that a worker chooses occupation $k$ is determined by the distribution of immigrants across occupations, by choice specific dummies, and by the interaction of choice specific dummies with individual characteristics. Note that for every individual we can observe both the percentage of immigrants in the occupation actually chosen, and that in occupations that were not chosen. Therefore, a conditional logit model is appropriate. The model is estimated using both one-digit and two-digit occupation cells. The results in Table 10 show that essentially differences in the percentage immigrants between occupations play no role in determining young immigrants' occupational choices.

Altogether, the results of this section illustrate that there is very little evidence that the immigrant inflows in given labor market segments led to voluntary outflows of natives from those occupations - either by voluntary quits or by changes in career choices.

\section{Conclusion}

In this paper we have studied the mass migration wave from the former Soviet Union to Israel in the 1990 s and its effect on native transitions from employment to non-employment. We find that there is a positive correlation between the share of immigrants in a given labor market segment and the probability of moving into nonemployment for native workers in that segment. However, this correlation is almost entirely spurious, as it is driven by immigrants selectively clustering into high turnover sectors. When we control for segment fixed effects we find that the effect is substantially reduced for males, and becomes zero, and at times even negative for females. Partitioning the labor market into segments based on predetermined skills (schooling and experience) is probably less likely to suffer from various forms of 
selection bias, and yields results that are more in line with standard economic theory. In any case the effect is not large: in our preferred specification, a 10 percentage point increase in the immigrant share raises employment to non-employment transition probabilities by at most 0.44 percent. We do find some evidence that male workers who were young, educated, worked in the private sector and were exposed to a large flux of newly arrived immigrants (as opposed to immigrants with some tenure in Israel) were more likely to be adversely affected by the migration wave. We reject the hypothesis that the relatively small magnitude of the effect is driven by offsetting flows of natives out of sectors with high immigrant shares.

Altogether, the results in this paper are in line with much of the previous research on the impact (or lack thereof) of immigration on native labor market outcomes, both in Israel and in other countries. Given the extraordinary size of the migration wave to Israel, especially in the first two years after the fall of the Soviet Union, our results are doubly surprising. It remains to be investigated whether the lack of any significant impact is due to the elasticity of labor demand, to complementarities between native and immigrant workers, or to large exogenous shocks to aggregate demand, such as the Oslo peace process or the global boom in the high tech sector. 


\section{References}

Altonji, Joseph G., and Card, David. "The Effects of Immigration on the Labor Market Outcomes of Less-Skilled Natives.” In Immigration, Trade and Labor, edited by John M. Abowd, and Richard B. Freeman. Chicago: University of Chicago Press, 1991.

Beenstock, Michael and Klinov, Ruth. "Why Did the Probability of Exiting Unemployment Decline? Israel, 1969-1992." The Maurice Falk Institute for Economic Research in Israel, Discussion Paper 96.12, December 1996.

Borjas, George J., Freeman, Richard B, and Katz, Lawrence, "Searching for the Effect of Immigration on the Labor Market”, American Economic Review, 86(2), May 1996 pp. 246-251.

Borjas, George J. "The Labor Demand Curve Is Downward Sloping: Reexamining the Impact of Immigration on the Labor Market." Quarterly Journal of Economics, 118(4), November 2003, pp.1335-1374.

Card, David. "The Impact of the Mariel Boatlift on the Miami Labor Market." Industrial and Labor Relations Review, 43(1), January 1990, pp. 245-257.

Card, David. "Immigrant Inflows, Native Outflows, and the Local Labor Market Impacts of Higher Immigration." Journal of Labor Economics, 19(1), January 2001, pp. 22-64.

Carrington, William J. and de Lima, Pedro J.F. "The Impact of 1970s Repatriates from Africa on the Portuguese Labor Market." Industrial and Labor Relations Review, 49(2), January 1996, pp. 330-347.

Cohen, Sarit and Tai-Hsieh, Chang, "Macroeconomic and Labor Market Impact of Russian Immigration in Israel”, May 2001, Bar Ilan University Working Paper No. 11-01.

Eckstein, Zvi and Weiss, Yoram., "On the Wage Growth of Immigrants: Israel 1990-2000."Journal of the European Economic Association, forthcoming.

Friedberg, Rachel M. "The Impact of Mass Migration on the Israeli Labor Market." Quarterly Journal of Economics, 116(4), November 2001, pp. 1373-1408.

Goldin, Claudia. "The Political Economy of Immigration Restriction in the United States, 1890-1921." In The Regulated Economy: A Historical Approach to Political Economy, edited by Claudia Goldin and G. Libecap. Chicago: University of Chicago Press, 1994. 
Hunt, Jennifer. "The Impact of the 1962 Repatriates from Algeria on the French Labor Market." Industrial and Labor Relations Review, 45(?), April 1992, pp. 556572.

LaLonde, Robert and Topel, Robert. "Labor Market Adjustments to Increased Immigration." In Immigration, Trade and Labor, edited by John M. Abowd, and Richard B. Freeman. Chicago: University of Chicago Press, 1991.

Pischke, Jorn-Steffen and Velling, Johannes. "Employment Effects of Immigration to Germany: An Analysis Based on Local Labor Markets." Review of Economics and Statistics, 79(4), November 1997, pp. 594-604. 


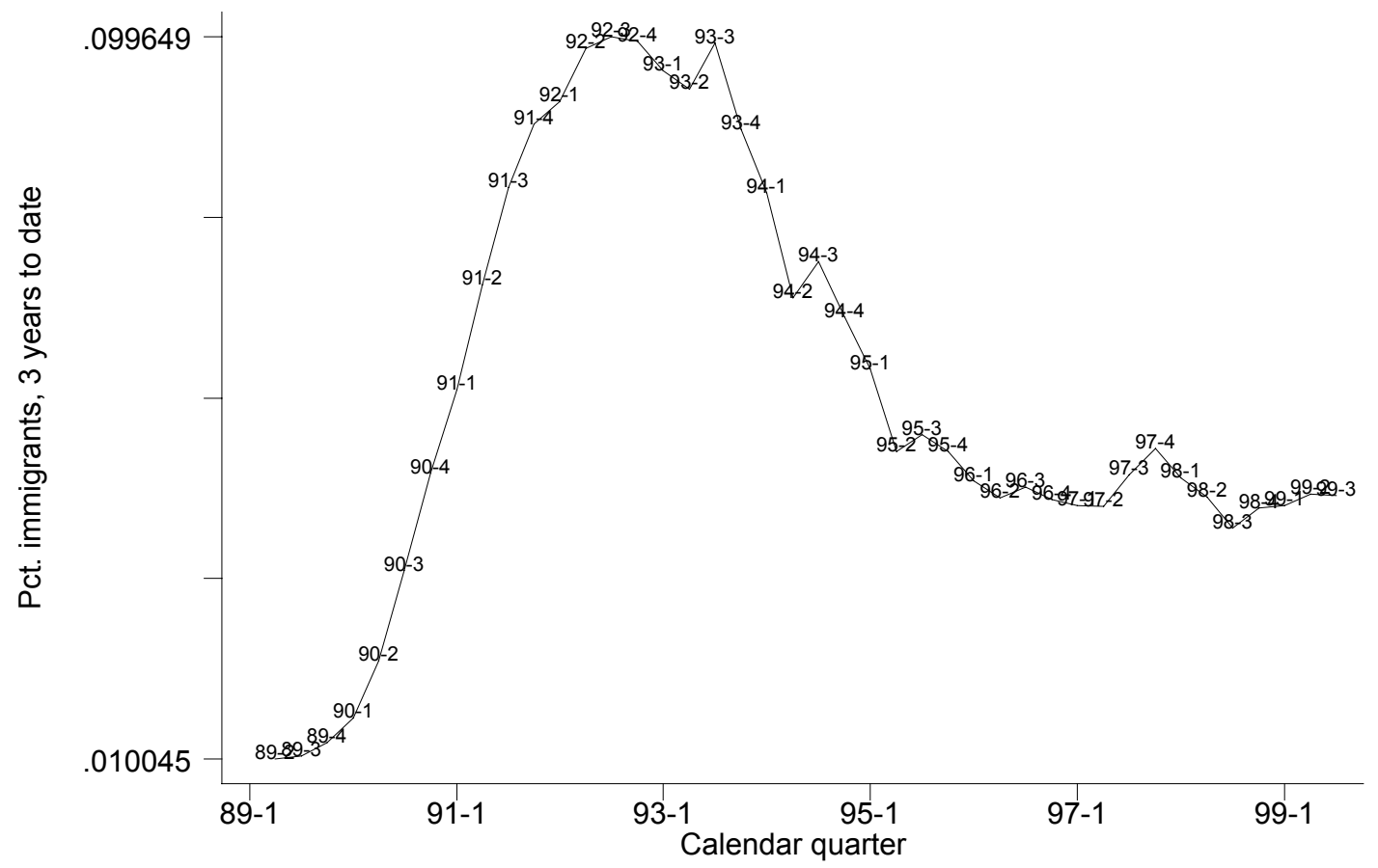

Figure 1a: Immigrant Flow, 1989-1999

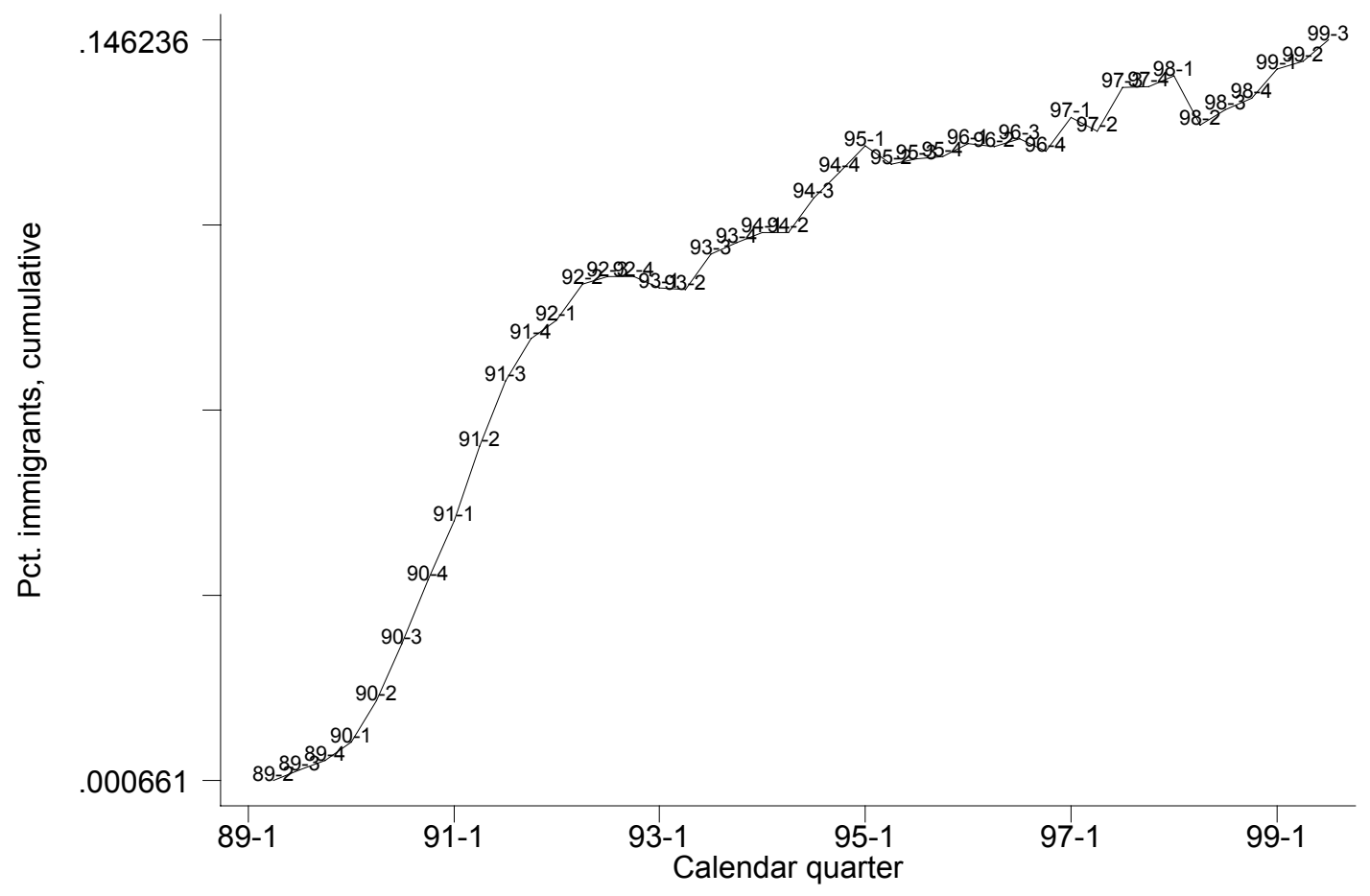

Figure 1b: Immigrant Stock, 1989-1999 
Table 1: Educational Distribution of Immigrants and Natives

Panel A: Males

\begin{tabular}{ccccc} 
& $\begin{array}{c}\text { All immigrants } \\
1989-1999\end{array}$ & $\begin{array}{c}\text { Immigrated in } \\
1989-1993\end{array}$ & $\begin{array}{c}\text { Immigrated in } \\
1994-1999\end{array}$ & Natives \\
\hline $\begin{array}{c}\text { Less than } \\
\text { High School }\end{array}$ & 9.54 & 8.33 & 11.18 & 32.40 \\
$\begin{array}{c}\text { High School } \\
\text { or Equivalent }\end{array}$ & 20.93 & 18.57 & 24.89 & 28.87 \\
$\begin{array}{c}\text { Some College } \\
\begin{array}{c}\text { College or } \\
\text { more }\end{array}\end{array}$ & 25.15 & 24.26 & 26.37 & \\
& 44.39 & 48.84 & & 15.72 \\
\end{tabular}

Panel B: Females

All immigrants Immigrated in Immigrated in Natives 1989-1999 1989-1993 1994-1999

Less than

High School

8.43

7.77

8.81

29.26

High School

or Equivalent

18.13

16.21

21.31

29.95

Some College

29.66

27.58

32.73

18.95

College or more

43.78

48.44

37.14

21.84 
Table 2: Occupational Distribution of Immigrants and Natives

\begin{tabular}{|c|c|c|c|c|c|}
\hline \multirow[t]{2}{*}{ Panel A: Males } & \multicolumn{2}{|c|}{$1989-1993$} & \multicolumn{3}{|c|}{ 1994-1999 } \\
\hline & $\begin{array}{c}\text { All } \\
\text { immigrants }\end{array}$ & Natives & $\begin{array}{c}\text { All } \\
\text { immigrants }\end{array}$ & $\begin{array}{c}\text { Recent } \\
\text { immigrants }\end{array}$ & Natives \\
\hline $\begin{array}{l}\text { Academic and } \\
\text { Scientific } \\
\text { Professionals }\end{array}$ & 12.02 & 9.41 & 12.94 & 6.91 & 10.16 \\
\hline $\begin{array}{l}\text { Associate } \\
\text { Professionals }\end{array}$ & 8.26 & 10.92 & 10.02 & 7.59 & 11.87 \\
\hline Managers & 0.40 & 8.61 & 1.74 & 1.47 & 9.60 \\
\hline Clerical Workers & 1.56 & 9.14 & 3.34 & 2.34 & 9.19 \\
\hline Sales Workers & 2.34 & 9.75 & 3.45 & 3.26 & 9.68 \\
\hline Service Workers & 14.17 & 8.16 & 13.52 & 17.27 & 9.48 \\
\hline $\begin{array}{l}\text { Skilled } \\
\text { Agricultural } \\
\text { Workers }\end{array}$ & 3.47 & 4.60 & 5.03 & 6.51 & 4.20 \\
\hline $\begin{array}{l}\text { Skilled Industry } \\
\text { Workers }\end{array}$ & 44.12 & 36.03 & 41.88 & 44.15 & 33.46 \\
\hline Unskilled Workers & 13.66 & 3.39 & 8.09 & 10.51 & 2.34 \\
\hline \multirow[t]{2}{*}{ Panel B: Females } & \multicolumn{2}{|c|}{ 1989-1993 } & \multicolumn{3}{|c|}{ 1994-1999 } \\
\hline & $\begin{array}{c}\text { All } \\
\text { immigrants }\end{array}$ & Natives & $\begin{array}{c}\text { All } \\
\text { immigrants }\end{array}$ & $\begin{array}{c}\text { Recent } \\
\text { immigrants }\end{array}$ & Natives \\
\hline $\begin{array}{l}\text { Academic and } \\
\text { Scientific } \\
\text { Professionals }\end{array}$ & 9.03 & 9.49 & 10.39 & 6.73 & 10.04 \\
\hline $\begin{array}{l}\text { Associate } \\
\text { Professionals }\end{array}$ & 14.40 & 26.51 & 13.79 & 9.07 & 25.68 \\
\hline Managers & 0.42 & 2.49 & 0.70 & 0.29 & 3.59 \\
\hline Clerical Workers & 7.82 & 27.62 & 9.90 & 6.01 & 30.09 \\
\hline Sales Workers & 4.99 & 7.71 & 6.37 & 5.64 & 7.47 \\
\hline Service Workers & 36.75 & 18.17 & 36.30 & 49.96 & 17.48 \\
\hline $\begin{array}{l}\text { Skilled } \\
\text { Agricultural } \\
\text { Workers }\end{array}$ & 2.24 & 1.27 & 3.79 & 4.11 & 1.21 \\
\hline $\begin{array}{l}\text { Skilled Industry } \\
\text { Workers }\end{array}$ & 15.37 & 5.42 & 13.83 & 12.72 & 3.74 \\
\hline Unskilled Workers & 8.97 & 1.32 & 4.94 & 5.48 & 0.70 \\
\hline
\end{tabular}


Table 3: Residential Distribution of Immigrants and Natives

\begin{tabular}{|c|c|c|c|c|c|}
\hline \multicolumn{3}{|c|}{ Panel A: Males } & \multirow[b]{3}{*}{$\begin{array}{c}\text { All } \\
\text { immigrants }\end{array}$} & \multirow[b]{2}{*}{ 1994-1999 } & \multirow[b]{3}{*}{ Natives } \\
\hline & \multicolumn{2}{|c|}{ 1989-1993 } & & & \\
\hline & $\begin{array}{c}\text { All } \\
\text { immigrants }\end{array}$ & Natives & & $\begin{array}{c}\text { Recent } \\
\text { immigrants }\end{array}$ & \\
\hline Jerusalem & 7.08 & 10.44 & 5.17 & 4.43 & 10.11 \\
\hline North & 13.33 & 16.68 & 13.29 & 11.66 & 17.56 \\
\hline Haifa & 17.98 & 13.86 & 16.03 & 16.51 & 13.32 \\
\hline $\begin{array}{c}\text { Tel Aviv (outer } \\
\text { circle) }\end{array}$ & 23.58 & 22.55 & 21.90 & 22.06 & 23.77 \\
\hline $\begin{array}{c}\text { Tel Aviv (inner } \\
\text { circle) }\end{array}$ & 20.61 & 23.68 & 17.96 & 21.60 & 21.52 \\
\hline South & 16.20 & 10.88 & 23.09 & 21.95 & 11.58 \\
\hline West Bank & 1.23 & 1.92 & 2.56 & 1.79 & 2.13 \\
\hline Panel B: & emales & & & & \\
\hline & $\begin{array}{c}\text { All } \\
\text { immigrants }\end{array}$ & Natives & $\begin{array}{c}\text { All } \\
\text { immigrants }\end{array}$ & $\begin{array}{c}\text { 1994-1999 } \\
\text { Recent } \\
\text { immigrants }\end{array}$ & Natives \\
\hline Jerusalem & 8.23 & 11.49 & 5.78 & 5.34 & 11.32 \\
\hline North & 13.26 & 15.98 & 13.07 & 11.68 & 16.93 \\
\hline Haifa & 18.33 & 13.44 & 16.45 & 17.00 & 13.13 \\
\hline $\begin{array}{l}\text { Tel Aviv (outer } \\
\text { circle) }\end{array}$ & 23.47 & 22.08 & 20.78 & 20.16 & 23.43 \\
\hline $\begin{array}{l}\text { Tel Aviv (inner } \\
\text { circle) }\end{array}$ & 19.21 & 24.60 & 18.10 & 21.49 & 21.98 \\
\hline South & 16.20 & 10.46 & 23.31 & 22.76 & 11.03 \\
\hline West Bank & 1.30 & 1.95 & 2.50 & 1.57 & 2.18 \\
\hline
\end{tabular}


Table 4: Summary Statistics

Males $\quad$ Females

Percentage Recent

Immigrants

4.63

5.18

Percentage All Immigrants

8.87

9.69

Percentage Natives Not

Employed

18.75

41.71

Quarterly Transition Rate from Employment to NonEmployment (Natives +

Non-Recent Immigrants)

Quarterly Transition Rate from Non-Employment to Employment (Natives +

9.06

Non-Recent Immigrants)

Total Number of Natives in Sample

48,902

50,523 
Table 5: Immigrant Flow and the Transition from Employment to NonEmployment

\begin{tabular}{|c|c|c|c|c|}
\hline & \multicolumn{2}{|c|}{ Males } & \multicolumn{2}{|c|}{ Females } \\
\hline & $\begin{array}{c}\text { No Cell } \\
\text { Fixed } \\
\text { Effects }\end{array}$ & $\begin{array}{l}\text { Cell Fixed } \\
\text { Effects }\end{array}$ & $\begin{array}{c}\text { No Cell } \\
\text { Fixed } \\
\text { Effects }\end{array}$ & $\begin{array}{c}\text { Cell Fixed } \\
\text { Effects }\end{array}$ \\
\hline $\begin{array}{l}\text { Definition of a Labor } \\
\text { Market Cell: }\end{array}$ & & & & \\
\hline $\begin{array}{l}\text { Two Digit } \\
\text { Occupation }\end{array}$ & $\begin{array}{c}0.069 \\
(.019) \\
{[37157]}\end{array}$ & $\begin{array}{c}0.026 \\
(.031) \\
{[37129]}\end{array}$ & $\begin{array}{c}0.303 \\
(.032) \\
{[27927]}\end{array}$ & $\begin{array}{c}-0.090 \\
(.046) \\
{[27780]}\end{array}$ \\
\hline $\begin{array}{l}\text { District of } \\
\text { Residence } \times \\
\text { Occupation }\end{array}$ & $\begin{array}{c}0.109 \\
(.020) \\
{[37267]}\end{array}$ & $\begin{array}{c}0.020 \\
(.037) \\
{[37245]}\end{array}$ & $\begin{array}{c}0.374 \\
(.032) \\
{[27969]}\end{array}$ & $\begin{array}{c}-0.033 \\
(.058) \\
{[27809]}\end{array}$ \\
\hline $\begin{array}{r}\text { Schooling } \times \\
\text { Occupation }\end{array}$ & $\begin{array}{c}0.082 \\
(.013) \\
{[36826]}\end{array}$ & $\begin{array}{c}0.037 \\
(.024) \\
{[36787]}\end{array}$ & $\begin{array}{c}0.250 \\
(.023) \\
{[27584]}\end{array}$ & $\begin{array}{c}-0.009 \\
(.046) \\
{[27555]}\end{array}$ \\
\hline $\begin{array}{r}\text { Industry } \times \\
\text { Occupation }\end{array}$ & $\begin{array}{c}0.107 \\
(.018) \\
{[37197]}\end{array}$ & $\begin{array}{c}0.013 \\
(.035) \\
{[36842]}\end{array}$ & $\begin{array}{c}0.452 \\
(.040) \\
{[27906]}\end{array}$ & $\begin{array}{c}-0.136 \\
(.054) \\
{[27674]}\end{array}$ \\
\hline $\begin{array}{r}\text { Schooling } \times \\
\text { Experience }\end{array}$ & $\begin{array}{c}0.0268 \\
(.022) \\
{[37646]}\end{array}$ & $\begin{array}{c}0.044 \\
(.023) \\
{[37628]}\end{array}$ & $\begin{array}{c}-0.052 \\
(.034) \\
{[28163]}\end{array}$ & $\begin{array}{c}0.009 \\
(.036) \\
{[28066]}\end{array}$ \\
\hline
\end{tabular}

Entries in the table represent the marginal effect (evaluated at the means of all the explanatory variables) of the percentage immigrants in one's cell on the probability of moving from employment to non-employment, as estimated by separate probit models. Immigrants are defined as those who have been in Israel less than three years. Robust standard errors in parentheses. Number of observations used in each model in brackets.

The sample includes natives and immigrants more than three years in Israel, who were employed on their first LFS interview, between 1989 and 1999. The male sample includes men between 25 and 65, the female sample includes women between 25 and 60. All regressions include the following variables: education, experience, experience squared; a dummy for married; dummies for the presence of children between 0 and 4, between 5 and 14, and between 15 and 17; a dummy for non-Jews; dummies for ethnic origin Asia-Africa and ethnic origin Europe-America-Oceania (third generation Israelis are the omitted category); a dummy for foreign born status and years since immigration (zero for natives); a full set of calendar quarter dummies. Observations with missing data were deleted. 


\section{Table 6: Immigrants Stock and the Transition from Employment to Non- Employment}

\begin{tabular}{|c|c|c|c|c|}
\hline & \multicolumn{2}{|c|}{ Males } & \multicolumn{2}{|c|}{ Females } \\
\hline & $\begin{array}{c}\text { No Cell } \\
\text { Fixed } \\
\text { Effects }\end{array}$ & $\begin{array}{l}\text { Cell Fixed } \\
\text { Effects }\end{array}$ & $\begin{array}{c}\text { No Cell } \\
\text { Fixed } \\
\text { Effects }\end{array}$ & $\begin{array}{l}\text { Cell Fixed } \\
\text { Effects }\end{array}$ \\
\hline $\begin{array}{l}\text { Definition of a Labor } \\
\text { Market Cell: }\end{array}$ & & & & \\
\hline $\begin{array}{l}\text { Two Digit } \\
\text { Occupation }\end{array}$ & $\begin{array}{c}0.023 \\
(0.011) \\
{[37157]}\end{array}$ & $\begin{array}{c}0.008 \\
(.020) \\
{[37129]}\end{array}$ & $\begin{array}{c}0.147 \\
(.018) \\
{[27927]}\end{array}$ & $\begin{array}{c}-0.161 \\
(.032) \\
{[27780]}\end{array}$ \\
\hline $\begin{array}{l}\text { District of } \\
\text { Residence } \times \\
\text { Occupation }\end{array}$ & $\begin{array}{c}0.061 \\
(.012) \\
{[37267]}\end{array}$ & $\begin{array}{c}0.016 \\
(.023) \\
{[37245]}\end{array}$ & $\begin{array}{c}0.184 \\
(.019) \\
{[27969]}\end{array}$ & $\begin{array}{c}-0.091 \\
(.035) \\
{[27809]}\end{array}$ \\
\hline $\begin{array}{r}\text { Schooling } \times \\
\text { Occupation }\end{array}$ & $\begin{array}{c}0.041 \\
(.008) \\
{[36826]}\end{array}$ & $\begin{array}{c}-0.001 \\
(.020) \\
{[36787]}\end{array}$ & $\begin{array}{c}0.138 \\
(.013) \\
{[27584]}\end{array}$ & $\begin{array}{c}-0.063 \\
(.033) \\
{[27555]}\end{array}$ \\
\hline $\begin{array}{r}\text { Industry } \times \\
\text { Occupation }\end{array}$ & $\begin{array}{c}0.042 \\
(.011) \\
{[37197]}\end{array}$ & $\begin{array}{c}-0.002 \\
(.022) \\
{[36842]}\end{array}$ & $\begin{array}{c}0.236 \\
(.024) \\
{[27906]}\end{array}$ & $\begin{array}{c}-0.113 \\
(.034) \\
{[27674]}\end{array}$ \\
\hline $\begin{array}{r}\text { Schooling } \times \\
\text { Experience }\end{array}$ & $\begin{array}{c}0.010 \\
(.014) \\
{[37554]}\end{array}$ & $\begin{array}{c}0.021 \\
(.018) \\
{[37554]}\end{array}$ & $\begin{array}{c}-0.038 \\
(.021) \\
{[28141]}\end{array}$ & $\begin{array}{c}-0.020 \\
(.026) \\
{[28102]}\end{array}$ \\
\hline
\end{tabular}

Entries in the table represent the marginal effect (evaluated at the means of all explanatory variables) of the percentage immigrants in one's cell on the probability of moving from employment to nonemployment, as estimated by separate probit models. Immigrants are defined as those who have been in Israel less than three years. Robust standard errors in parentheses. Number of observations used in each model in brackets.

The sample includes natives and immigrants more than three years in Israel, who were employed on their first LFS interview, between 1989 and 1999. The male sample includes men between 25 and 65, the female sample includes women between 25 and 60 . All regressions include the following variables: education, experience, experience squared; a dummy for married; dummies for the presence of children between 0 and 4, between 5 and 14, and between 15 and 17; a dummy for non-Jews; dummies for ethnic origin Asia-Africa and ethnic origin Europe-America-Oceania (third generation Israelis are the omitted category); a dummy for foreign born status and years since immigration (zero for natives); a full set of calendar quarter dummies. Observations with missing data were deleted. 
Table 7: The Effect of the Number of Immigrants and Tenure in Israel on the Transition from Employment to Non-Employment

\begin{tabular}{|c|c|c|c|c|}
\hline \multirow{3}{*}{ Panel A: Males } & \multicolumn{4}{|c|}{ Definition of Labor Market } \\
\hline & (1) & (2) & (3) & (4) \\
\hline & $\begin{array}{l}\text { Two Digit } \\
\text { Occupation }\end{array}$ & $\begin{array}{l}\text { Two Digit } \\
\text { Occupation }\end{array}$ & $\begin{array}{l}\text { Schooling } \times \\
\text { Experience }\end{array}$ & $\begin{array}{l}\text { Schooling } \times \\
\text { Experience }\end{array}$ \\
\hline $\begin{array}{l}\text { Total number of } \\
\text { immigrants in cell }\end{array}$ & $\begin{array}{c}2.90 \times 10^{-4} \\
\left(4.18 \times 10^{-4}\right)\end{array}$ & $\begin{array}{c}1.27 \times 10^{-3} \\
\left(1.01 \times 10^{-3}\right)\end{array}$ & $\begin{array}{c}2.40 \times 10^{-3} \\
\left(1.50 \times 10^{-3}\right)\end{array}$ & $\begin{array}{c}5.63 \times 10^{-3} \\
\left(2.64 \times 10^{-3}\right)\end{array}$ \\
\hline $\begin{array}{c}\text { Total number of } \\
\text { immigrants weighted } \\
\text { by experience in Israel }\end{array}$ & - & $\begin{array}{l}-2.04 \times 10^{-4} \\
\left(1.78 \times 10^{-4}\right)\end{array}$ & - & $\begin{array}{l}-6.86 \times 10^{-4} \\
\left(4.52 \times 10^{-4}\right)\end{array}$ \\
\hline $\begin{array}{c}\text { Effect of an added } \\
5,000 \text { immigrants with } \\
0 \text { years of experience } \\
\text { in Israel }\end{array}$ & 0.0015 & 0.00635 & 0.0120 & 0.0282 \\
\hline $\begin{array}{c}\text { Effect of an added } \\
5,000 \text { immigrants with } \\
5 \text { years of experience } \\
\text { in Israel }\end{array}$ & 0.0015 & 0.00125 & 0.0120 & 0.0110 \\
\hline Cell fixed effects & Yes & Yes & Yes & Yes \\
\hline $\begin{array}{c}\text { Number of } \\
\text { observations }\end{array}$ & 36183 & 36183 & 35979 & 35979 \\
\hline \multirow[t]{2}{*}{ Panel B: Females } & \multicolumn{4}{|c|}{ Definition of Labor Market } \\
\hline & $\begin{array}{c}\text { (1) } \\
\text { Two Digit } \\
\text { Occupation } \\
\end{array}$ & $\begin{array}{c}\text { (2) } \\
\text { Two Digit } \\
\text { Occupation }\end{array}$ & $\begin{array}{c}(3) \\
\text { Schooling } \times \\
\text { Experience }\end{array}$ & $\begin{array}{c}(4) \\
\text { Schooling } \times \\
\text { Experience }\end{array}$ \\
\hline $\begin{array}{l}\text { Total number of } \\
\text { immigrants in cell }\end{array}$ & $\begin{array}{l}-1.56 \times 10^{-3} \\
\left(5.96 \times 10^{-4}\right)\end{array}$ & $\begin{array}{l}-2.02 \times 10^{-3} \\
\left(1.27 \times 10^{-3}\right)\end{array}$ & $\begin{array}{c}8.11 \times 10^{-4} \\
\left(2.16 \times 10^{-3}\right)\end{array}$ & $\begin{array}{l}1.03 \times 10^{-3} \\
\left(3.73 \times 10^{-3}\right)\end{array}$ \\
\hline $\begin{array}{c}\text { Total number of } \\
\text { immigrants weighted } \\
\text { by experience in Israel }\end{array}$ & - & $\begin{array}{l}1.07 \times 10^{-4} \\
\left(2.34 \times 10^{-4}\right)\end{array}$ & - & $\begin{array}{l}-4.68 \times 10^{-5} \\
\left(6.31 \times 10^{-4}\right)\end{array}$ \\
\hline $\begin{array}{c}\text { Effect of an added } \\
5,000 \text { immigrants with } \\
0 \text { years of experience } \\
\text { in Israel }\end{array}$ & -0.00780 & -0.01010 & 0.0041 & 0.0052 \\
\hline $\begin{array}{c}\text { Effect of an added } \\
5,000 \text { immigrants with } \\
5 \text { years of experience } \\
\text { in Israel }\end{array}$ & -0.00780 & -0.00743 & 0.0041 & 0.0040 \\
\hline Cell fixed effects & Yes & Yes & Yes & Yes \\
\hline $\begin{array}{c}\text { Number of } \\
\text { observations }\end{array}$ & 26670 & 26670 & 26421 & 26421 \\
\hline
\end{tabular}

Entries in the table represent the marginal effect (evaluated at the means of all explanatory variables) of the relevant variable on the probability of moving from employment to non-employment, as estimated by a probit model. Immigrants are all those who immigrated after 1989. For the full list of control variables, see Table 5. Robust standard errors in parentheses. 
Panel A: Males

Percentage Immigrants

0.091

0.043

$(.032)$

$-0.004$

Percentage Immigrants $\times$

Experience

Percentage Immigrants $\times$

(Years of Schooling - 12)

0.008

$(.0038)$

Percentage Immigrants $\times$

Private Sector

$-$

$(0.047)$

Two Digit Occupation Fixed Effects

Yes

Yes

Yes

Number of Observations

37129

37129

37065

\section{Panel B: Females}

(1)

$-0.023$

(.074)

$-0.002$

(.002)

$$
(.002)
$$

Experience

Percentage Immigrants $\times$

(Years of Schooling - 12)

Percentage Immigrants $\times$

Private Sector

Number of Observations

27780

$-0.075$

(.052)

$-0.189$

$(.061)$

Entries in the table represent the marginal effect (evaluated at the means of all explanatory variables) of the relevant variable on the probability of moving from employment to non-employment, as estimated by a probit model. Immigrants are those in Israel less than three years. The definition of the labor market cell is the two-digit occupation cell. For a full list of control variables, see Table 5. Robust standard errors in parentheses. 
Table 9: Quits and Firings

Dependent Variable: Employment status in period 2 - 4 categories.

Estimation method: multinomial logit

Panel A: Males

Two Digit Occupation

Schooling-Experience

\begin{tabular}{|c|c|c|c|c|}
\hline & \multicolumn{2}{|c|}{ Two Digit Occupation } & \multicolumn{2}{|c|}{ Schooling-Experience } \\
\hline & Coefficient & $\begin{array}{c}\text { Implied } \\
\text { Elasticity }\end{array}$ & Coefficient & $\begin{array}{c}\text { Implied } \\
\text { Elasticity }\end{array}$ \\
\hline $\begin{array}{l}\text { Fired: Percentage } \\
\text { Immigrants in Cell }\end{array}$ & $\begin{array}{c}1.328 \\
(1.427)\end{array}$ & 0.075 & $\begin{array}{c}2.624 \\
(1.300)\end{array}$ & 0.107 \\
\hline $\begin{array}{l}\text { Quit: Percentage } \\
\text { Immigrants in Cell }\end{array}$ & $\begin{array}{l}-0.432 \\
(2.776)\end{array}$ & -0.030 & $\begin{array}{l}-0.825 \\
(2.439)\end{array}$ & -0.035 \\
\hline $\begin{array}{c}\text { Moved to OLF: } \\
\text { Percentage Immigrants in } \\
\text { Cell }\end{array}$ & $\begin{array}{c}1.206 \\
(1.170)\end{array}$ & 0.061 & $\begin{array}{c}1.049 \\
(0.860)\end{array}$ & 0.044 \\
\hline Cell fixed effects & & & & \\
\hline Number of Observations & & & & \\
\hline
\end{tabular}

\begin{tabular}{|c|c|c|c|c|}
\hline \multirow[t]{3}{*}{ Panel B: Females } & \multirow{2}{*}{\multicolumn{2}{|c|}{ Two Digit Occupation }} & \multirow{2}{*}{\multicolumn{2}{|c|}{ Schooling-Experience }} \\
\hline & & & & \\
\hline & Coefficient & $\begin{array}{c}\text { Implied } \\
\text { Elasticity }\end{array}$ & Coefficient & $\begin{array}{c}\text { Implied } \\
\text { Elasticity }\end{array}$ \\
\hline $\begin{array}{l}\text { Fired: Percentage } \\
\text { Immigrants in Cell }\end{array}$ & $\begin{array}{l}-0.828 \\
(2.032)\end{array}$ & -0.030 & $\begin{array}{l}1.998 \\
(1.610)\end{array}$ & 0.095 \\
\hline $\begin{array}{l}\text { Quit: Percentage } \\
\text { Immigrants in Cell }\end{array}$ & $\begin{array}{l}-2.126 \\
(2.912)\end{array}$ & -0.080 & $\begin{array}{l}-1.585 \\
(2.322)\end{array}$ & -0.065 \\
\hline $\begin{array}{l}\text { Moved to OLF: } \\
\text { Percentage Immigrants in } \\
\text { Cell }\end{array}$ & $\begin{array}{l}-2.060 \\
(.847)\end{array}$ & -0.094 & $\begin{array}{c}0.218 \\
(0.638)\end{array}$ & 0.010 \\
\hline Cell fixed effects & \multicolumn{2}{|c|}{ Yes } & \multicolumn{2}{|c|}{ Yes } \\
\hline Number of Observations & \multicolumn{2}{|c|}{27841} & \multicolumn{2}{|c|}{27479} \\
\hline $\begin{array}{l}\text { Entries in the table } r \\
\text { specified outcome relativ } \\
\text { multinomial logit model. T } \\
\text { the time of the first intervi } \\
\text { control variables, see Table }\end{array}$ & nt the effe & $\begin{array}{l}\text { rcentage } \\
\text { - "rem } \\
\text { tives an } \\
\text { in Isra } \\
\text { in pare }\end{array}$ & $\begin{array}{l}\text { nts on the } 1 \\
\text { mployed" - } \\
\text { amigrants w } \\
\text { in three year }\end{array}$ & $\begin{array}{l}\text { Ids ratio of } \\
\text { stimated b } \\
\text { re employe } \\
\text { the full lis }\end{array}$ \\
\hline
\end{tabular}


Table 10: Immigrants and Young Workers' Occupational Choices - A Conditional Logit Model

\begin{tabular}{lcc}
\hline Panel A: Males & $\begin{array}{c}\text { Conditional Logit Model } \\
\text { Choice Set: One Digit } \\
\text { Occupations }\end{array}$ & $\begin{array}{c}\text { Conditional Logit Model } \\
\text { Choice Set: Two Digit } \\
\text { Occupations }\end{array}$ \\
\hline $\begin{array}{c}\text { Coefficient on Percentage } \\
\text { Immigrants in Cell }\end{array}$ & -0.372 & 0.083 \\
$(1.428)$ & $(.281)$ \\
$\begin{array}{c}\text { Number of Alternatives in } \\
\text { Choice Set }\end{array}$ & 9 & 86 \\
$\quad$ & 16641 \\
Number of Individuals in & & \\
Sample & 16681 & \\
\end{tabular}

\begin{tabular}{|c|c|c|}
\hline Panel B: Females & $\begin{array}{c}\text { Conditional Logit Model } \\
\text { Choice Set: One Digit } \\
\text { Occupations }\end{array}$ & $\begin{array}{c}\text { Conditional Logit Model } \\
\text { Choice Set: Two Digit } \\
\text { Occupations }\end{array}$ \\
\hline $\begin{array}{l}\text { Coefficient on Percentage } \\
\text { Immigrants in Cell }\end{array}$ & $\begin{array}{l}-0.848 \\
(1.509)\end{array}$ & $\begin{array}{l}-0.079 \\
(.340)\end{array}$ \\
\hline $\begin{array}{c}\text { Number of Alternatives in } \\
\text { Choice Set }\end{array}$ & 9 & 84 \\
\hline $\begin{array}{c}\text { Number of Individuals in } \\
\text { Sample }\end{array}$ & 13751 & 13727 \\
\hline \multicolumn{3}{|c|}{$\begin{array}{l}\text { The estimates in the Table represent the coefficient on percentage immigrants in a conditional } \\
\text { logit model. The one-digit model also includes choice-specific dummies, and interactions between the } \\
\text { choice specific dummies and the following variables: years of education, age, dummies for marital } \\
\text { status and ethnic origin, a foreign born dummy and years since immigration, and year dummies. The } \\
\text { two-digit model also includes choice specific dummies, and interactions between the one digit choice } \\
\text { specific dummies and the explanatory variables. The sample includes workers between } 25 \text { and } 35 \text { years } \\
\text { old who were employed at the time of the first interview. Immigrants are those in Israel less than } 3 \\
\text { years. }\end{array}$} \\
\hline
\end{tabular}

